\title{
VINTE ANOS DEPOIS: A CONSTRUÇÃO DEMOCRÁTICA BRASILEIRA VISTA DA PERIFERIA DE SÃO PAULO
}

Gabriel de Santis Feltran

Durante o regime militar brasileiro, uma fronteira nítida distinguia os grupos sociais oficialmente legítimos daqueles a serem banidos da convivência pública. Cabia ao Estado legislar sobre essa distinção e à repressão oficial manter esta fronteira ativa, impedindo que a pluralidade da sociedade fosse representada politicamente. O bloqueio seletivo do acesso à legitimidade pública desenhava a face autoritária do sistema político. Até por isso, foi só durante a decadência do regime militar que alguns dos segmentos sociais reprimidos puderam se articular, ainda que fossem muito distintos entre si, em torno da reivindicação comum de espaços de expressão política. Os principais atores populares desta reivindicação foram chamados de "novos movimentos sociais".

Este artigo conta a história de um destes atores, o Movimento de Defesa do Favelado (MDF), que desde o final dos anos 1970 atua na periferia leste da cidade de São Pauloº ${ }^{2}$ Ao

\footnotetext{
${ }^{1}$ Paoli (1995) capta com muita sensibilidade este sentido propriamente político da aparição dos movimentos sociais populares do período.

2 A reconstrução dessa trajetória está amparada em pesquisa de caráter etnográfico, realizada junto ao MDF na Zona Leste de São Paulo, entre 2001 e 2003. Este artigo resume e atualiza o centro dos argumentos de pesquisa mais extensa, que
} 
narrar esta história de trinta anos, vinte dos quais vividos sob a "nova democracia" brasileira, o texto destaca as diferentes modalidades de relação entre os setores populares e a esfera política no Brasil contemporâneo. De um lado, aparecem as mediações, discursivas e institucionais, construídas nas últimas décadas na tentativa de diluir a fronteira que bania os segmentos populares da representatividade política; de outro lado, podem ser vistas as fronteiras recentes que, ainda que sob um regime pautado pela universalidade formal de direitos, se repõem atualmente entre os setores populares e o mundo político. A garantia de legitimidade à presença dos setores populares no mundo público aparece então como uma questão incontornável da construção da pluralidade do sistema político, pressuposto da noção de democracia.

Como se sabe, a efervescência movimentista da virada para os anos 1980 foi, em São Paulo, gerada pela aparição conjunta, na cena pública, dos seguintes segmentos sociais: 84 i) grupos pauperizados das periferias urbanas, reivindicando melhorias sociais objetivas, organizados por vertentes da igreja católica inspiradas pela teologia da libertação; ii) grupos de sindicalistas que renovavam o ideário socialistaoperário do período, na esteira das mobilizações dos metalúrgicos do $\mathrm{ABC}$; iii) setores jovens da classe média e das elites intelectuais, que nas universidades haviam conhecido o marxismo e os movimentos "libertários" do norte 3 .

No interior deste campo, legitimado também por frações minoritárias das elites e da imprensa ${ }^{4}$, articulavam-se

incluiu ainda outro movimento e foi publicada integralmente em Feltran (2005). Agradeço aos integrantes do MDF e a Evelina Dagnino, que apoiaram a pesquisa de modo decisivo, e a Adrián Gurza Lavalle pelo estímulo para que este texto fosse escrito. Os nomes próprios citados, à exceção das figuras públicas, são fictícios.

${ }^{3}$ Para além da renovação das matrizes discursivas centrais para estas mobilizações (católica, sindical e marxista - ver o trabalho paradigmático de Eder Sader, 1988), estes setores intelectualizados traziam a influência cultural das transformações americana e européia que se seguiu à aparição dos movimentos de direitos civis e de maio de 1968 .

${ }^{4}$ Como a Ordem dos Advogados do Brasil, grandes jornais da imprensa escrita paulistana etc. A grande mobilização pelas Diretas Já!, por exemplo, já seria um 
grupos tão díspares quanto favelados e feministas, estudantes trotskistas e jovens negros, militantes da pastoral da juventude e homossexuais, operários, ambientalistas e lideranças políticas recém-chegadas do exílio. As disputas privadas entre estes setores eram conhecidas internamente, mas a aliança conjuntural marcante entre eles, na leitura pública, explicava-se em negativo: todos estes grupos viviam a condição comum de baixíssima representatividade durante o regime anterior e percebiam na ação conjunta uma possibilidade de expressar publicamente suas identidades e interesses. As falas destes atores, aproveitando-se dos vazios discursivos próprios das transições de poder, permitiram mesmo que se conformasse no país uma espécie de "contraesfera pública" que, paralela à transição institucional "lenta, segura e gradual" posta em marcha pelos militares, abriu espaços renovados para a construção democrática.

Esta esfera pública nascente ofereceu uma caixa de ressonância fundamental para os novos movimentos sociais, em particular os de caráter popular, que puderam ser lidos então como os "novos personagens" da cena política brasileira ${ }^{6}$. Ora, se estes movimentos efetivamente interferiam na discussão pública, estando fora das mediações institucionais constituídas, constatou-se ainda neste contexto o alargamento da política para além dos marcos institucionais ${ }^{7} \mathrm{e}$

marco dessa aliança, inteiramente conjuntural, criada pela existência, naquele momento, de um inimigo comum determinado.

${ }^{5}$ Evidentemente, empresto aqui a expressão de Habermas (1992), que de algum modo já antecipa a crítica que Fraser (1995) elaboraria à sua noção de espaço público dos anos 1960. Em linhas gerais, entretanto, minhas referências para pensar o privado, o social e o político no estudo dos movimentos sociais vêm da leitura de Hannah Arendt. Na literatura brasileira, Costa (1997) já usou a noção habermasiana de "contra-esfera pública" ou "esfera pública alternativa" para pensar a transição de regime.

${ }^{6}$ Utilizando-me da expressão que dá título ao trabalho de Sader (1988). Para excelentes revisões e classificações da imensa bibliografia sobre os movimentos sociais de até meados dos anos 1990, segundo diferentes perspectivas analíticas, ver Baierle (1992), Doimo (1995) e Paoli (1995).

${ }^{7}$ Diversos trabalhos de referência para a literatura do período caminham clara- 
a elaboração em curso de uma "nova noção de cidadania", concebida como uma estratégia de democratização conjunta do Estado e das relações sociais ${ }^{8}$.

Foi esta leitura eminentemente política dos movimentos populares que os figurou, nas análises acadêmicas e nas disputas de poder efetivas, como atores de relevância central para a construção democrática. Militantes e analistas empenhados no aprofundamento democrático concordaram que estes atores expressavam publicamente os interesses dos setores populares, até então alijados da política pela tradição autoritária brasileira, e daí seu impacto democratizante. Ao reivindicarem bens sociais publicamente, os movimentos populares forjariam não apenas ações específicas de superação de suas carências imediatas, como também uma ruptura com o autoritarismo político: os direitos renovados que eles pautavam seriam ancorados tanto nas leis quanto na construção de uma cultura mais democrática ${ }^{9}$. Instituíase neste momento um nexo normativo bastante forte entre as noções de democracia política e de justiça social, que permaneceu durante as décadas seguintes como o pressuposto

mente nesta direção. Para citar alguns, Sader (1988, p. 312) cita a "ampliação" da política com base na criação de "uma nova concepção da política, constituída a partir das questões da vida cotidiana e da direta intervenção dos interessados". Evers (1984, pp. 12-13) comenta que "os esforços das ditaduras militares para suprimir a participação política [...] tiveram o efeito exatamente oposto de politizar as primeiras manifestações sociais por moradia, consumo, cultura popular e religião". Santos (1994, p. 225) argumenta que "a novidade dos novos movimentos sociais não reside na recusa da política, mas, pelo contrário, no alargamento da política para além do marco liberal da dicotomia entre Estado e Sociedade Civil”. ${ }^{8}$ Dagnino (1994). a qual se refere ao 1994a.

9 Telles (1994, pp. 91-2) explicita a ruptura em jogo naquele contexto: "Não se trata aqui, é preciso esclarecer, de negar a importância da ordem legal e da armadura institucional garantidora da cidadania e da democracia. A questão é outra. $\mathrm{O}$ que se está aqui propondo é pensar a questão dos direitos em outro registro. Pois, pelo ângulo da dinâmica societária, os direitos dizem respeito, antes de mais nada, ao modo como as relações sociais se estruturam. [...] Seria possível dizer que, na medida em que são reconhecidos, os direitos estabelecem uma forma de sociabilidade regida pelo reconhecimento do outro como sujeito de interesses válidos, valores pertinentes e demandas legítimas". 
central, quase naturalizado, de grande parte das análises sobre a democratização brasileira. A construção da democracia, centro de elaboração do projeto político em pauta nas esquerdas do país, produziria igualdade social.

Vinte anos depois, esse nexo entre transformação política e mudança social perdeu sua capacidade explicativa. A construção democrática brasileira tem sido marcada e pautada, ao contrário das expectativas militantes, justamente pela contradição marcante entre a consolidação formal do Estado de direito (permeada inclusive pela implementação de um sistema amplo e bem-sucedido de participação política da sociedade civil na expansão das políticas sociais $\left.{ }^{10}\right) \mathrm{e}$ a persistência (ou agravamento) da desigualdade social. Ao contrário do aprofundamento da democracia às relações sociais, o período democrático recente foi marcado pela explosão da violência e aumento do desemprego estrutu$\mathrm{ral}^{11}$, especialmente nos grandes centros urbanos, onde a sociabilidade pública sofreu restrição importante.

Os movimentos populares sentiram na pele esta contradição. Como atores políticos instituídos, estes movimentos tiveram ambientes públicos cada vez mais estáveis para atuar. Conforme o tempo passava, os marcos legais se tornavam mais progressistas, os canais de relação com o Estado mais numerosos e melhor instituídos, e apareciam possibilidades reais de participação efetiva na formulação de políticas públicas setoriais. Como organizações sociais das periferias urbanas, entretanto, estes mesmos movimentos passaram a

\footnotetext{
${ }^{10}$ Ver especialmente Avritzer e Navarro (2003) ou Ribeiro e Grazia (2003). As relações entre política e sociedade no Brasil têm merecido destaque em muitas publicações recentes, como, por exemplo, em Paoli e Telles (2001), Dagnino (2002), Dagnino, Olvera e Panfichi (2006), Carvalho (1997), Oliveira e Paoli (2000), entre outros.

${ }^{11}$ Dados da PED (Pesquisa Emprego e Desemprego - Convênio Seade-Dieese) na Região Metropolitana de São Paulo indicam Taxa de Desemprego Total de 9,6\% em 1986, chegando a 18,7\% em 2004, com pico de mais de $20 \%$ em vários meses entre 2002 e 2005 (últimos dados anuais disponíveis). A pesquisa indica ainda uma diminuição significativa nos rendimentos reais dos trabalhadores empregados no período democrático, apesar da pequena recuperação visualizada nos últimos anos.
} 
conviver com a instabilidade de um tecido social cada vez mais inseguro, tanto pelas novas formas de trabalho, cada vez menos afeitas a garantir direitos, quanto pela explosão da violência, que apareceu cada vez mais próxima dos cotidianos $^{12}$. Este texto explora alguns elementos deste paradoxo, constitutivo da atuação contemporânea dos movimentos populares, a partir de um olhar retrospectivo sobre o percurso de três décadas do MDF.

\section{Nas pistas do movimento de defesa do favelado}

\section{Anos 1970}

Não era a política que movia as reuniões da Legião de Maria, grupo de religiosas católicas que, em meados dos anos 1970, rezavam de casa em casa na favela da Vila Prudente, Zona Leste de São Paulo. Ler trechos da bíblia entre os favelados era parte da missão de confortar com preces o sofrimento 88 de pessoas, de todo lado do Brasil, que já há algum tempo chegavam em grandes levas para "tentar a vida" em São Paulo. Para estes migrantes, o trabalho numa terra de progresso seria o signo de uma ascensão social possível, e o sofrimento de viver em lugares sem água, luz ou dono seria depois - esse era o plano - o fundamento da narrativa dos pioneiros: "quando nós chegamos, aqui em volta era tudo mato".

Mas a reza de casa em casa ganhou outros significados com o passar dos anos. No final da década de 1970, a teologia da libertação já contaminava setores relevantes da Igreja

\footnotetext{
${ }^{12}$ A violência, aliás, é hoje a categoria central de quase todas as narrativas de vida dos que nasceram nas margens de expansão das cidades nas últimas décadas. O estigma das "classes perigosas" segue operante: os anos 1990 foram repletos de produção de narrativas jornalísticas e cinematográficas sobre a explosão de uma violência considerada "banal" nas grandes cidades, que contaminou também a produção bibliográfica: o sucesso de relatos como os de Barcellos (2004); Soares, Bill e Athayde (2005), Ferréz (2005) e Lins (1997) é, de modos distintos, parte do mesmo fenômeno. Num contraponto a essa tendência, Alba Zaluar segue oferecendo pistas relevantes (ver uma compilação de seu trabalho recente em Zaluar, 2004) para pensar as relações entre periferias urbanas, violência e democratização.
} 
Católica e já tinha o aval da Confederação Nacional dos Bispos do Brasil, cujas lideranças influenciavam diretamente as comunidades de base e pastorais em São Paulo. Foi nessa época que novos missionários chegaram à favela da Vila Prudente, e as reuniões de reza passaram também a discutir temas mundanos: a precariedade da moradia, o cheiro do esgoto a céu aberto, a falta de água e luz para as famílias, de creches e escolas para as crianças, a violência ${ }^{13}$.

Aos poucos, de um trabalho estritamente religioso desenhava-se uma prática social popular, ancorada numa narrativa simultaneamente socialista e cristã, que já chegava aos moradores de favelas embebida da legitimidade própria dos religiosos junto aos setores populares. A "opção preferencial pelos pobres" professada pelos novos padres e irmãs, agora também moradores das periferias urbanas, encontrava um solo propício para se desenvolver. Além de os "pobres" serem muitos, os vínculos entre a religiosidade e a celebração do trabalho e do progresso, presentes nesta narrativa, casavam-se perfeitamente com a utopia privada das famílias que chegavam às periferias: "Deus há de dar um trabalho pra gente progredir, ser alguém na vida”.

Neste contexto, a reza na Vila Prudente se tornou um meio para organizar "o povo" em ações de melhoria concreta das condições de vida. Grupos de jovens, estudantes e moradores passaram a auxiliar os religiosos nos cultos e especialmente nas ações comunitárias, que incluíam desde salas de alfabetização de adultos, seguindo o método de Paulo Freire,

\footnotetext{
${ }^{13}$ Importante ressaltar que os relatos de pesquisa já identificam a presença da violência urbana entre as favelas paulistanas no final dos anos 1970, embora o crescimento alarmante do tema ocorra nas décadas seguintes. A violência praticamente não aparece na literatura específica sobre os movimentos sociais da periferia, em parte pela legítima recusa dos autores em reforçar o estereótipo trazido pelas teorias da marginalidade, que associavam diretamente pobreza e violência, e em parte porque esta violência nascente, sendo considerada subproduto direto da desigualdade, deveria ser suplantada pela democratização da cena política, que se mostrava viável pela ascensão dos movimentos populares.
} 
até a construção da rede de esgoto canalizado da favela, em mutirão tocado pelos próprios moradores. A concretização de benefícios fundamentais ao morador da favela foi aos poucos ampliando a participação nos grupos comunitários, que se encontravam toda semana. Alguns dos favelados paulistanos, envolvidos diretamente nas mobilizações, começaram então a circular por reuniões crescentemente politizadas. Nestes espaços, jovens militantes conheceram a fama das personagens de esquerda que voltavam do exílio, e fazer parte das suas lutas os estimulava a seguir reunindo os moradores de cada favela, às vezes mais de uma vez na semana, para "fazer alguma coisa".

Já na virada para os anos 1980, a abertura do regime favorecia a circulação de discursos novos nestas reuniões. As notícias das greves que estouravam no ABC, onde alguns moradores da Vila Prudente trabalhavam, chegaram rápido e trouxeram à baila conversas sobre um sindicalismo combativo, que impunha respeito ao patronato. As narrativas celebravam o poder popular de transformação e as virtudes das classes populares. As teleologias cristã e socialista se encontravam sobre um pano de fundo favorável: a população lutava por ascensão social, o progresso do mundo levaria à transformação, as classes populares seriam as protagonistas da conquista de justiça social.

Na favela da Vila Prudente já se falava também das articulações em torno da criação de um partido político de trabalhadores, nas quais estariam presentes muitas das lideranças "progressistas" da Igreja Católica (como Dom Luciano Mendes de Almeida, que apoiava diretamente as lideranças dessa favela), além dos sindicalistas do ABC, como Lula. Muitos dos personagens que voltavam do exílio político também se empenharam na criação do partido em São Paulo, como Paulo Freire, que passou a freqüentar assiduamente as reuniões da "comunidade" da Vila Prudente. Um partido de trabalhadores, construído coletiva e organicamente, seria a possibilidade de migração efetiva das 
demandas e anseios das comunidades de periferia para a esfera política ${ }^{14}$. O partido "representaria" politicamente os setores populares organizados e, até por isso, seus procedimentos internos de organização foram, naquele contexto, muito parecidos aos utilizados para organizar os trabalhos de base junto aos setores populares ${ }^{15}$.

Os moradores da Vila Prudente envolvidos nas reuniões locais, minoria estrita dos milhares de indivíduos que já viviam pela favela, começaram também a circular por espaços ampliados de militância - as reuniões do sindicato, do partido, as manifestações em frente a prédios públicos. É recorrente, ao entrevistar militantes de movimentos desse período, que suas narrativas sejam profundamente subjetivas - relatos de emancipação pessoal e política - ao se recordarem das lutas neste contexto. Circulando pela cidade os favelados sentiam ter voz e descobriam o mundo; contar suas histórias em espaços ampliados já era fazer política. Os anos seguintes foram invariavelmente intensos para estas pessoas e, sem que se notasse, logo os favelados da Vila Prudente e seus assessores passaram a se chamar de "movimento". Foi assim que surgiu, sem nenhum tipo de formalização, o Movimento de Defesa do Favelado, conhecido por todos como MDF.

\footnotetext{
${ }^{14} \mathrm{O}$ PT vai hegemonizar este campo de discursos em São Paulo e em algumas outras capitais importantes, desde sua fundação, embora alguns grupos de esquerda não aderissem à aposta na democracia liberal como caminho para a transformação social. Parte destes grupos nunca se inseriu no PT, mantendo-se politicamente muito restrita, e parte retirou-se ou foi expulsa no correr dos anos, conforme o programa do partido migrava para o centro. No Rio de Janeiro e no sul do país, o PDT e outros partidos de esquerda também executaram papel importante na agregação dos setores movimentistas. Partidos como o PMDB e o PSDB, com trajetórias muito distintas, também oferecerão nortes programáticos a pessoas e organizações que haviam se empenhado na queda da ditadura, mas não se identificavam com o programa de transformação à esquerda que o PT trazia fortemente desde sua criação.

${ }^{15} \mathrm{Um}$ militante dos movimentos sociais do período, brincando sobre essa proximidade entre movimento, trabalhos comunitários, partido e sindicato, conta que ela se materializava em reuniões: "das $2 \mathrm{~h}$ às $5 \mathrm{~h}$ : das $2 \mathrm{~h}$ às $3 \mathrm{~h}$ era Pastoral, das $3 \mathrm{~h}$ às $4 \mathrm{~h}$ movimento sindical, das $4 \mathrm{~h}$ às $5 \mathrm{~h}$ era PT. Só mudava a pauta, mas as pessoas eram as mesmas!".
} 


\section{Anos 1980}

Logo na primeira metade da década de 1980, dada a efetiva abertura do regime político e a circulação cada vez mais maciça de discursos de crítica ao passado autoritário, os participantes do MDF sentiram que a realidade conspirava a seu favor. O Brasil progredia, a destituição do regime autoritário significaria transformação rumo à igualdade social, e era hora de apostar alto na política. O governo municipal de São Paulo, a partir de 1983, também imerso nesta renovação discursiva ${ }^{16}$, passou a considerar os moradores das favelas como merecedores dos serviços públicos de água e luz. Já não era possível ignorar tanta gente, e marcava-se assim uma diferença importante em relação aos governos anteriores, cuja política para as favelas estava centrada nas tentativas de remoção ${ }^{17}$.

Ao mesmo tempo, o novo governo sabia que a distribuição pública de serviços essenciais aos domicílios, ao longo de algum tempo, poderia ser utilizada pelas famílias faveladas para legitimar a posse do terreno ocupado ${ }^{18}$. Para defenderse desta possibilidade, as empresas públicas passaram a instalar nas favelas pontos de distribuição coletiva de água e luz, às vezes um ponto para 100 ou 200 casas. As pessoas passaram a buscar água nesses pontos coletivos e a fazer suas ligações

\footnotetext{
${ }^{16}$ Mário Covas foi o prefeito de São Paulo pelo MDB, indicado por Franco Montoro, de maio de 1983 ao final de 1985.

${ }^{17}$ Foram recorrentes na pesquisa as referências ao governo municipal Jânio Quadros como o período de maior intensidade nas tentativas de remoção, como neste trecho de uma das principais lideranças do movimento: "era muito grande o povo que vinha sofrendo, com o Jânio, com outros governos, que queriam mais desfavelar, que entendiam a favela como desfavelamento, levar o favelado, construir casa, construir projeto pra levar pra longe".

18 "Por que é que o poder público não queria ligar [água e luz nas favelas]? Não é que os favelados não pagassem pelo risco de inadimplência não. É que o recibo configurava posse. Se você provar que você pagou uma conta de luz, ou uma conta de água há tantos anos, hoje, por exemplo, te dá direito de usucapião. Ou seja, a posse da terra se configura pela comprovação do tempo que você utiliza aquela terra. Portanto era por isso que eles não queriam institucionalizar o acesso a esse direito, de água e luz" [Erundina]. (Doravante, os nomes dos entrevistados em pesquisa empírica aparecem entre colchetes.)
} 
de luz a partir dos postes instalados nas redondezas. Como o regime de cobrança das empresas é progressivo, conforme o uso, os pontos coletivos de distribuição geraram contas astronômicas e não era possível pagá-las. A saída privada foi partir para as ligações clandestinas, individualizadas, mas o MDF viu aí um rebaixamento do estatuto de cidadania dos moradores de favela e resolveu protestar publicamente. Iniciou-se assim uma articulação específica, entre pequenos grupos militantes das favelas de São Paulo, em torno da luta pelo abastecimento individualizado de água e luz. Essa articulação interessava a muitos, no entanto, e ampliou significativamente os participantes do MDF.

As discussões entre estes grupos transformaram-se na luta pela "taxa mínima de água e luz" para os moradores de favela, que foi referida, durante toda a pesquisa empírica que realizei, como a primeira grande reivindicação coletiva do MDF. Era a primeira vez, em já alguns anos de mobilização, que o movimento julgava adequado pressionar o governo. Antes disso, agia-se no plano local e em busca de melhorias pontuais, como nos mutirões informais para a construção do esgoto na Vila Prudente, mas não se mexia com os atores públicos formais. A partir de agora, num cenário mais democrático, seria preciso pressionar os governantes para que cumprissem o seu papel público: o favelado agora seria cidadão e, portanto, poderia exigir seus direitos sociais. Era uma outra gramática política que se colocava em marcha.

A dimensão do processo político que se iniciava ali ainda era insuspeitada. A luta pela "taxa mínima" cresceu tanto e gerou tanta mobilização de base que nos debates públicos veio à tona um dado notável: quase metade da população de São Paulo morava em favelas, cortiços ou áreas irregulares. Em 1983, esta luta foi então assumida pela vereadora recém-eleita Luiza Erundina, do PT, cujo histórico de atuação militante em diversas favelas de São Paulo produzia iniciativas similares às da Vila Prudente. Erundina, eleita 
vereadora basicamente pelo voto dos favelados, articulava em torno do seu mandato parlamentar o Movimento Unificado de Favelas (MUF), ao qual o MDF aderiu imediatamente ${ }^{19}$. Em abril de 1984, o MDF e o MUF marcaram presença no comício histórico pelas "Diretas Já!" para presidente, no Vale do Anhangabaú. Os militantes do período se lembram muito mais, entretanto, da manifestação de 13 de junho de 1984, quando o MUF foi em passeata ao Palácio do Governo exigir a "taxa mínima" para os favelados. Ainda que intensamente reprimido pelas "forças da ordem", o movimento conseguiu o que queria. Uma semana depois, seus representantes foram recebidos pelas empresas públicas de distribuição, para fecharem o acordo que estabelecia a cobrança de uma "taxa social" domiciliar de água e luz para os moradores das favelas de São Paulo ${ }^{20}$.

Essa conquista pública fortaleceu todo o movimento, e isso repercutiu também na Vila Prudente. A demonstra94 ção de benefícios concretos aos favelados, obtidos pela ação coletiva, trazia mais moradores para "a luta"; e as assembléias do MUF lotadas deixavam claro que havia muitos outros grupos de favelados mobilizados como eles. O movimento dos favelados construía poder político e, portanto, mudava o diagrama de compreensão de suas privações: as mazelas sociais das maiorias deixavam de ser figuradas como fracasso pessoal ou familiar e passavam a ser vistas como injustiça social. Como era o Estado autoritário o principal adversário daquele campo, ainda no início dos anos 1980, foi simples supor que as injustiças sociais viriam a ser suplantadas pela democratização. Os setores populares que aderiram ao que

\footnotetext{
${ }^{19}$ Tanto a criação do PT, quanto da Central Única dos Trabalhadores (CUT) e do MUF respondiam, em diferentes escalas, à intencionalidade estratégica de produzir sujeitos políticos representativos de setores sociais até então destituídos do cenário político, em período de transição de regime.

${ }^{20}$ Vale ressaltar que o acordo não foi legalizado, mas assumido pelas empresas e cumprido até recentemente, quando essas empresas foram privatizadas.
} 
seria posteriormente chamado de "projeto democráticopopular", do qual o PT foi ator central, claramente traziam consigo esta demanda.

O nexo entre o clima de democratização política e a promessa de justiça social do período fortaleceu estes movimentos de base, e o MDF cresceu muito nos anos 1980. Na estratégia de unificação das lutas, muitas outras favelas menos organizadas foram agrupadas sob o guarda-chuva do movimento, em toda a "Região Episcopal Belém", para utilizar o termo das comunidades de base. O MDF seria o representante dos interesses das favelas dos distritos de Ipiranga, Belém, Vila Prudente, Parque São Lucas, Sapopemba e São Mateus, com vínculos fortes também em Santo André. A expansão rápida do movimento demandou mudanças em sua organização interna: decidiu-se pela manutenção e remuneração de uma equipe central de militantes, para possibilitar maior dedicação aos trabalhos e maior atenção às articulações mais amplas do "campo movimentista" ${ }^{21}$.

O organograma do MDF passou a prever, a partir daí, três instâncias de suporte a essa equipe de militantes profissionais: i) suporte popular pelas lideranças de base das quase 40 favelas já vinculadas ao MDF naquele momento, que engrossavam as mobilizações e possibilitavam capilaridade às ações; ii) suporte por técnicos especialistas (advogados, arquitetos, engenheiros), que acompanhavam e assessoravam as obras empreendidas, bem como as ações públicas e demandas do campo; e iii) suporte por políticos e parlamentares (em geral ex-militantes jovens do movimento eleitos vereadores ou deputados estaduais), que atuavam junto ao partido e nos parlamentos como portadores dos interesses do movimento. Religiosamente, as assembléias mensais do MDF unificavam este grupo todo na discussão e deliberação das linhas gerais de atuação.

\footnotetext{
${ }^{21}$ Essa equipe central de lideranças do MDF era paga com recursos obtidos junto às organizações católicas Cafod e Trocaire, da cooperação internacional irlandesa.
} 
Vale lembrar que, graças ao papel articulador representado no cenário mais amplo, o PT e os "intelectuais orgânicos" do partido, entre eles os assessores do movimento, já apareciam como atores centrais do campo movimentista também em esfera mais ampla. Nos trabalhos de base católicos e na formação sindical, os militantes recém-chegados passavam a ser estimulados a freqüentar também as reuniões do partido e a considerar sua centralidade para a transformação social e popular em vista.

Já no começo desse processo, em 1985, o MDF se tornou uma figura jurídica, o que facilitaria as relações institucionais do movimento com os governos e outros órgãos de financiamento externo. Tanto a direção como as lideranças de favelas e assessorias se tornaram sócias da entidade: o MDF deixava de ser uma organização comunitária, centrada na Vila Prudente, e se tornava um movimento articulador de entidades comunitárias, agora com sede em um escritó96 rio na Vila Alpina. Esta fórmula de organização interna, que obteve recursos internacionais de organizações religiosas por mais de duas décadas seguidas, sustentou materialmente o movimento até os dias de hoje.

O MDF passava então a intermediar diversas escalas de atuação social e política; seu modo de agir se tornava muito mais complexo. Para que se tenha uma idéia disso, o movimento que nasceu na favela da Vila Prudente em 1978, sete anos depois já atuava em mais de 40 favelas da Zona Leste, estimulando em cada uma delas a execução de obras coletivas de melhoria, em regime de mutirão autônomo, e a organização política dos favelados. A Vila Prudente seguia dando o exemplo: depois de concluídas as obras do esgoto canalizado, foram construídas, ainda nos anos 1980, uma creche comunitária e uma casa de cultura, além de reformadas algumas vielas e barracos em situação de risco.

No plano político municipal, o MUF percebia que, após a conquista da taxa mínima de água e luz, era preciso haver 
uma nova bandeira agregadora dos diversos movimentos comunitários esparsos pela cidade. A estratégia foi então lançar, já em 1986, uma nova campanha geral, de interesse de todos: a luta pela Concessão do Direito Real de Uso (CDRU). Do ponto de vista urbanístico as favelas seguiam irregulares, e mesmo que o desfavelamento já não fosse politicamente viável, nenhum morador possuía a documentação formal da casa em que vivia e, portanto, nem garantia legal do direito à permanência nela nem a possibilidade de passá-la aos seus filhos. O "movimento de favela", como se referem ao MUF muitos dos militantes daquele período, assumiu então a causa da regularização fundiária em São Paulo, pregando a posse coletiva da terra, com garantia legal e individualizada para o uso dos moradores ${ }^{22}$.

Havia uma distinção política fundamental entre essa nova luta, pela CDRU, e a anterior, pela taxa mínima de água e luz. Se na primeira mobilização as favelas se contentaram com um acordo extra-oficial junto às empresas prestadoras de serviços, que garantia um benefício social (a taxa mínima de água e luz para moradores de favela, apesar de concretizada naquele período, não se materializou na forma de lei e, portanto, não garantiu o direito legal após a privatização destas empresas), no caso da CDRU a luta exigia garantia legal de direitos. A pressão já era pela garan-

\footnotetext{
${ }^{22}$ Este instrumento jurídico ativava entre os militantes a memória das lutas da Assembléia do Povo de Campinas (1979 e 1981 - ver Dagnino, 1994b). Marcelo, um dos principais assessores do MDF, advogado e hoje assessor parlamentar, caracteriza juridicamente essa proposta: "o trabalho que a gente fez, de mais significado, eu acho que foi a luta pela posse da terra, quando nós discutimos com a população a questão da Concessão do Direito Real de Uso, que é um instituto jurídico que foi feito na época da ditadura, 1967, um decreto-lei ainda, que constitui esse instituto. E nós usamos esse instituto exatamente pra garantir a posse do pessoal, levando em consideração que você não fica com a propriedade, você garante esse exercício. Não é uma questão precária, é um direito real, então a pessoa pode registrar esse direito real. [...] Não chega a ser uma escritura, mas é um documento que confere a ele o direito da posse da terra, por um prazo longo, e que você acaba com aquele temor da desocupação. Isso foi amplamente discutido nos núcleos de favela".
} 
tia do direito fundamental à moradia, na letra da lei, para todos os favelados de São Paulo.

A mobilização de base para pressão política seguia como a estratégia central do movimento, mas era agora associada à ação institucional de advogados e assessores técnicos, que estudavam qual seria a melhor forma de garantir o direito à terra aos favelados, mantendo o princípio de não defender a propriedade privada ${ }^{23}$. Na aparição deste tipo de ação mais formal dos movimentos, o partido tornou-se também mais central para a mobilização: os movimentos contavam com a negociação da aprovação do projeto da CDRU na Câmara dos Vereadores, o que se faria, em última análise, pela atuação dos parlamentares petistas eleitos por eles. Desde este período, em São Paulo, o PT passou então a ser o mediador político fundamental entre os movimentos sociais e a institucionalidade política. Não foi então por acaso que o MDF se vinculou ao partido, como dezenas de outros movimen98 tos semelhantes, e passou a enfatizar a atuação política às ações pontuais de melhoria em cada favela assessorada ${ }^{24}$.

Também não foi por acaso que a Campanha da Fraternidade da CNBB, em 1986, teve como tema "Terra de Deus,

\footnotetext{
23 "Até aqui estava garantido que eles resistiriam, pra não serem despejados, mas isso era uma situação instável, precária, então era preciso garantir a sua permanência nas áreas, através do direito real de uso. E aí veio toda uma discussão que teve uma importância política grande, no seio do próprio movimento: seria um direito individual, família por família, ou seria um direito coletivo, direito real de uso da área como um todo, para o conjunto daquelas famílias. E aí houve divergência no movimento. [...] A vertente mais avançada do movimento, da qual nós participávamos, desde a origem, entendíamos que seria um avanço a posse coletiva, o direito real de uso coletivo, a posse coletiva, pra não reproduzir a propriedade capitalista, o princípio capitalista da propriedade. Porque você termina reproduzindo, né? A família que está com dificuldade financeira vende, e especula, dentro da própria [favela]". [Erundina]

${ }^{24} \mathrm{O}$ que é bastante claro para as lideranças do MDF: "e depois a gente começou num trabalho mais político mesmo, né? A partir de representar o MDF noutras organizações, na época era o MUF (Movimento Unificado de Favelas) [...] [depois na $U M M]$, então a gente foi ampliando nesse sentido. Depois um pouco, nos últimos anos, na relação com a Câmara Municipal, né? Que a gente tem relação com alguns parlamentares do PT, né, então também nessa dimensão mais realmente política”. [Sônia]
} 
terra de irmãos". Os movimentos de base, conectados até então a atores de relevância nacional como a CNBB, produziam ações articuladas. A campanha pautava os debates da reforma agrária e urbana, com vistas às mobilizações sociais em torno da Assembléia Nacional Constituinte que se gestava. O suporte e a legitimidade da CNBB, neste ano, foram decisivos para a luta da CDRU entre 1986 e 1988. Foram anos agitadíssimos para o MDF. Os militantes dividiam-se entre a luta pela Concessão do Direito Real de Uso da terra para todas as favelas da cidade de São Paulo, as mobilizações político-partidárias em torno da Constituinte e a atuação política das igrejas e comunidades de base, que assessoravam dezenas de associações comunitárias da Zona Leste.

Foi o estágio mais avançado do movimento, me diria Luiza Erundina, quase vinte anos depois, referindo-se à luta pela CDRU. Ninguém melhor que ela para constatar a relevância política daquele momento: na esteira da popularidade conquistada como uma das lideranças desse processo de lutas, Luiza Erundina teve legitimidade suficiente para, em 1988, tornarse a candidata do PT à prefeitura de São Paulo, em disputa partidária que contou com Plínio de Arruda Sampaio. Não havia expectativa de vitória a princípio, mas a campanha cresceu muito nas semanas finais, e Erundina terminou por vencer as eleições municipais, tornando-se a primeira mulher a governar a cidade de São Paulo, e pelo PT. Esta surpresa, mesmo para os favelados de São Paulo, fez com que todo o cenário de atuação política do MDF se alterasse radicalmente ${ }^{25}$.

A nova prefeita de São Paulo não tinha apenas sua origem política nos movimentos de favela; ela ainda era parte integrante e fundamental da articulação destes movimentos.

\footnotetext{
${ }^{25}$ São inúmeras as referências à surpresa dos militantes na constatação da vitória eleitoral do PT em 1988. Erundina foi eleita numa conjuntura específica, com o diferencial relevante do voto útil das classes médias contra Paulo Maluf; mas efetivamente teve suas bases eleitorais entre as populações faveladas das Zonas Sul e Leste do município de São Paulo.
} 
A eleição de Erundina não poderia deixar de ser lida, por estes setores mobilizados, como a ascensão deles próprios ao Executivo municipal. A representatividade dos setores populares pelos movimentos e pelo PT, mais do que nunca, era considerada um dado natural. A composição dos quadros de confiança da prefeitura empossada em 1989 se fez, quase que inteiramente, na distribuição negociada de cargos a ex-lideranças populares de movimentos, até ali organizados informalmente ou precariamente institucionalizados, além dos sindicalistas e intelectuais vinculados ao $\mathrm{PT}^{26}$.

\section{Anos 1990}

O governo da maior cidade do país, na virada para os anos 1990, situava em definitivo o PT como partido relevante para o cenário político nacional. Nas favelas da Zona Leste da cidade, o MDF passava evidentemente a atuar como um dos braços de sustentação do Executivo municipal. 100 Se há alguns anos o movimento se fortalecia justamente na pressão contra os governos e na articulação ampla de grupos favelados em torno de um discurso autonomista, agora ele se sentia parte de uma administração municipal, o que implicava não só apoiar o partido e o governo em cada debate, ou cada arena de relação entre movimentos e governo, mas contribuir efetivamente para a administração dos programas de governo implementados. A natureza mesma do movimento como ator social e político deveria ser alterada, e assim se fez.

O MDF que há pouco tempo administrava apenas os recursos de manutenção, ou obtidos em festas religiosas e rifas comunitárias, para realizar obras pontuais nas favelas,

\footnotetext{
${ }^{26}$ A presença inicial de nomes como Paulo Freire (Educação), Eduardo Jorge (Saúde), Marilena Chauí (Cultura) e Nabil Bonduki (Habitação) nas secretarias de governo, todos eles até ali bastante envolvidos na militância junto aos setores populares, fazia do governo Erundina um espaço bastante aberto para as ações articuladas com os movimentos sociais.
} 
agora precisava se organizar para o engajamento efetivo na gestão de grandes projetos municipais para a população favelada. Muitas vezes, o movimento se viu discutindo e negociando projetos públicos sobre o imenso mapa da cidade, com recursos em pauta até então inimagináveis. Era a discussão sobre a "gestão de políticas públicas" chegando, de uma vez por todas, aos movimentos populares. $\mathrm{O}$ amadurecimento do debate político no interior do MDF a partir desta experiência é inegável; o movimento se tornava um ator político constituído em solo mais firme, o que almejava há tempos, e atuaria na interface entre governos e sociedade civil mediando a construção de políticas públicas.

Evidentemente, a construção artesanal das relações entre o movimento e as suas bases nas favelas, que o legitimava publicamente, passou a ser feita com menos afinco. A estrutura de mediação entre Estado e sociedade estava em plena construção, e os movimentos sociais foram forçados a assumir sua tarefa nela às custas de submeter-se, conscientemente, à falta de tempo e ao excesso de trabalho que acompanham os militantes de um processo político desta magnitude. Agora na Prefeitura, além do mais, o movimento tratava de projetos de amplitude bem maior e, portanto, deveria considerar não apenas suas bases específicas a cada ação planejada. Ao contrário, deveria levar em conta uma série muito mais extensa e plural de sujeitos populares, desde as organizações de base vinculadas a outros partidos políticos até os clubes desportivos e organizações filantrópicas, passando pelos interesses privados de vereadores, condomínios, comerciantes etc. As negociações e os diagramas de resolução de conflitos se tornaram bem mais complexos e exigiam qualificações específicas. Passaram a ser mais valorizados internamente ao campo militante, para este perfil de atuação, os indivíduos leais à gestão municipal (e ao partido) e que fundamentalmente estivessem capacitados, do ponto de vista técnico, para auxiliar na tarefa de 
administrar a cidade de São Paulo. Boa parte dos quadros populares dos movimentos como o MDF, quase sempre formados na atuação militante e pastoral, pouco escolarizados e capacitados formalmente para a gestão, passou a ocupar cargos subalternos tanto no governo quanto no partido.

A conseqüência lógica desse processo é que, apesar das mudanças internas, as organizações populares, comunitárias e religiosas como o MDF passaram a ocupar espaços bem menos relevantes na disputa política interna ao governo, e é o partido político que vai progressivamente assumindo papel de ator central no campo "democrático-popular"27. No âmbito interno ao PT as mudanças também eram profundas: a partir da primeira grande derrota eleitoral para presidente, em 1989, e das primeiras administrações municipais importantes nacionalmente (São Paulo, Porto Alegre, Vitória), o partido decidia caminhar para um programa paulatinamente mais instrumental, centrado na ascensão ao Estado: se antes a mudança (ou a construção da hegemonia) partiria das bases, agora percebia-se que o Estado deveria ser o lócus de irradiação do projeto de transformação à esquerda. A partir do Estado, o partido construiria uma "democracia participativa" que poderia radicalizar a participação popular na esfera política. O partido pautava assim um papel específico para os movimentos populares como o MDF; seus quadros deveriam, agora, ser também submetidos a "formações" e "capacitações" para esta nova tarefa. Militantes de base passaram então a conviver com inúmeras ofertas de cursos de "formação de lideranças", "capacitação para gestão de políticas públicas" etc.

No MDF não foi diferente, e uma das primeiras conseqüências deste cenário foi a tradução silenciosa do movimento de favelas em movimento de moradia. Se no cená-

\footnotetext{
${ }^{27}$ As diferenças entre as formas de organização do movimento e do partido, aliás, que na origem eram mais retóricas que práticas, passaram também a se estabelecer muito mais claramente a partir daqui.
} 
rio anterior, para fazer pressão era necessário agregar-se ao máximo a outros movimentos, e daí um MUF fazia todo sentido, agora que o movimento é governo, quanto mais setorializadas e específicas as demandas, mais ágeis podem ser as soluções. A pulverização do MUF entre movimentos e grupos com demandas setoriais foi inevitável, e é este um dos fatores do declínio rápido da aparição pública do "movimento de favela" durante a gestão Erundina. Surgiu, entretanto, uma série renovada de fóruns temáticos e entidades articuladoras setoriais, especializadas nas relações de grupos movimentistas organizados por demandas com as secretarias de governo (saúde, educação, moradia, assistência social, saneamento, obras etc.). O MDF abandonou a amplitude dos temas reivindicados pelas favelas; traduzia-se num movimento de moradia e, mais tarde filiou-se à União dos Movimentos de Moradia (UMM).

Até por isso, a atuação do movimento no governo Erundina se concentrou nas relações com a Secretaria Municipal de Habitação. Como se sabe, as políticas de habitação popular naquela gestão do PT tiveram como estratégia principal a realização de mutirões habitacionais autogeridos, com intensa participação dos movimentos sociais de base na gestão dos canteiros de obras ${ }^{28}$. O MDF tornou-se parceiro direto da prefeitura municipal em vários destes mutirões, na Zona Leste de São Paulo ${ }^{29}$. Construir centenas de casas populares em mutirão, em cada canteiro de obras, exigia do movimento uma habilidade gerencial impressionante, além de uma série de competências profissionais específicas.

Entraram então em cena as assessorias técnicas dos mutirões, contratadas pela prefeitura, e que trabalharam

${ }^{28} \mathrm{O}$ debate sobre essas iniciativas é imenso na literatura sobre o urbanismo em São Paulo e reverbera ainda hoje. Para uma descrição interna ao governo Erundina, ver Andrade, Rosseto e Bonduki (1993).

${ }^{29}$ Inclusive nos mutirões históricos para o movimento de habitação em São Paulo, como a Fazenda da Juta, no distrito de Sapopemba. 
muito próximas dos movimentos de moradia durante toda a década de $1990^{30}$. Esta nova composição de atores contribuiu para que se consolidasse o perfil de atuação movimentista mais competente gerencial e tecnicamente e mais centrado na intermediação entre decisões de governo e execução de políticas públicas. Efetivamente, os setores populares organizados em movimentos passavam a se constituir mais solidamente como atores políticos, encontrando nas parcerias com o Estado para execução de programas de governo o seu nicho de atuação pública. Estas mudanças internas não são privilégio do MDF, evidentemente: elas fazem notar o desenvolvimento do processo que a literatura dos movimentos sociais denominou como sua "inserção institucional" "31. Em meados dos anos 1990, a tecnificação e a profissionalização das organizações sociais e populares já era uma tendência da estrutura associativa da sociedade civil brasileira. Nesta passagem, a "contra-esfera pública" 104 movimentista dos anos 1970 e 1980 também se inseriu institucionalmente, e seus atores passaram a fazer parte do jogo político constituído.

Os anos de mudança intensa sempre passam rápido. O governo Erundina já estava no final quando foi levado para a Câmara Municipal o projeto de regulamentação da Concessão do Direito Real de Uso da terra para as favelas. Tramitando desde 1986, o projeto seria votado ainda durante o "governo popular", mas em cenário político já radicalmente diferente daquele que o instituiu. Como não poderia deixar de ser, a negociação desse processo já foi quase inteiramente represada aos espaços institucionais, e a setorialização

\footnotetext{
${ }^{30}$ Essas assessorias, em geral ONGs constituídas por arquitetos e engenheiros, também faziam parte do campo das esquerdas, em geral por terem sido constituídas como um contraponto às empreiteiras, que dominavam o mercado da construção civil e as licitações públicas em todo o país.

${ }^{31}$ Inserção essa exaustivamente debatida na literatura de até meados dos anos 1990 e valorada de modos muito diversos. Ver, por exemplo, as distintas conclusões de Doimo (1995) e Carvalho (1997).
} 
dos movimentos, com o declínio do MUF, já não permitia tanta pressão conjunta sobre a Câmara de Vereadores. Os grupos de oposição à prefeitura também já disputavam de modo mais feroz a base eleitoral crescente das favelas e cortiços $^{32}$, e o projeto de lei não passou. Faltou um único voto, o de Biro-Biro, ex-jogador do Corinthians, que mudou de idéia no último momento. A frustração foi grande no MDF: as lideranças disseram ter perdido motivação, e os moradores de favela, que já não acompanharam de tão perto as discussões, permaneceram sem a garantia legal do direito de habitar a metrópole ${ }^{33}$. Foi assim que o governo Erundina terminou para o MDF.

Tudo seria ainda bem pior para o movimento a partir de 1993, com a derrota do PT nas duas eleições municipais que se seguiram. Paulo Maluf assumiu a prefeitura municipal e, no pólo oposto do espectro ideológico, tinha os movimentos populares vinculados ao PT como adversários diretos. Na área da habitação, os mutirões foram paralisados e os contratos com as assessorias técnicas não foram renovados; o movimento passou então a conviver também com a escassez dos recursos materiais para a execução de projetos. Outras "políticas públicas" entraram em cena e, no caso das favelas, durante o governo Maluf teve imensa visibilidade em São Paulo a construção de prédios populares do "Projeto Cingapura" ${ }^{34}$. O MDF, de co-gestor destas

\footnotetext{
${ }^{32}$ Especialmente os setores liderados por Walter Feldman, que articulavam uma série de favelas e cortiços ex-participantes do MUF para combater a noção da posse coletiva da CDRU, apostando em um projeto que favorecesse o mecanismo de compra e venda das casas pelos moradores de favelas.

${ }^{33} \mathrm{O}$ Estatuto da Cidade, em contexto novamente muito distinto, fundamentaria na década seguinte a regularização das condições de ocupação das áreas de favela em todo o país.

${ }^{34} \mathrm{O}$ Projeto Cingapura foi fundamental na política habitacional do prefeito Paulo Maluf (1993-1996), elaborada em evidente reação ao crescimento dos mutirões, na maioria autogeridos por movimentos populares da gestão anterior (Luiza Erundina, 1989-1992). A despeito das resistências moleculares, o projeto foi implementado amplamente e teve continuidade na gestão Celso Pitta (1997-2000).
} 
políticas, passou então a se ver na posição de combatê-las publicamente, tendo por vezes que disputar com o novo governo suas antigas lideranças de base, especialmente nas favelas beneficiadas pelo Cingapura ${ }^{35}$.

Todo o campo dos movimentos populares de São Paulo acabara de fazer um esforço enorme de reestruturação, interna e externamente, para atuar como governo, alinhado aos marcos político-partidários e às necessidades da gestão ${ }^{36}$. Entretanto, o novo governo já não queria mais estes movimentos. Também já não era mais possível, com a nova estrutura organizativa do campo movimentista, mobilizar as bases populares para fazer resistência: nas mudanças de contexto, a capacidade reivindicativa de todo o campo já declinara definitivamente. Em meados dos anos 1990, pela perda de uma esfera pública reivindicativa que lhes oferecia caixa de ressonância aos discursos, as narrativas socialistas e politizadas do MDF junto à grande maioria dos favelados, e mesmo perante o mundo público, já pareciam palavras ao vento.

Para continuar sobrevivendo como ator político durante as gestões Maluf e Pitta o MDF dedicou-se ao PT. Materialmente, o movimento ainda contou com recursos para sua manutenção vindos da cooperação internacional religiosa, e parte da equipe técnica passou também a atuar na assessoria a mandatos de parlamentares petistas. O MDF, que entrara na década de $1990 \mathrm{em}$ seu auge, saiu dela em seu momento mais difícil. A despeito da sua consolidação

\footnotetext{
${ }^{35}$ Sônia, uma das lideranças históricas do MDF, narra esse processo de disputas pela base nos termos da "cooptação": "Nos últimos anos (1993-2000), Maluf e Pitta deram uma arrebentada. Cooptaram liderança, [...] coisa assim, que você entregou a noiva pronta, quer dizer, uma favela que a gente acompanhava [...] na época a Luiza [Erundina] deixou inacabado, aí ele [Maluf] terminou rápido. Cooptou uma das lideranças, que as outras também já estavam com muitos anos de luta, cansados, então é um exemplo: não fomos convidados [o MDF] nem pra inauguração [do conjunto habitacional]".

36 "Porque queira ou não queira, o MDF, pra se fortalecer, depende do Poder Público. Por mais que você crie coisas alternativas, é uma relação assim, forte com a Prefeitura" [Sônia].
} 
como ator político, o movimento passou a conviver nestes anos com uma questão até então insuspeitada: sua representatividade junto aos setores favelados, antes um dado natural, agora era progressivamente desafiada.

\section{Anos 2000}

Enquanto o MDF se transformava para acolher as novas demandas do sistema político, as favelas de São Paulo também se transformaram muito profundamente: os meninos e meninas nascidos nas periferias da cidade no final dos anos 1970, portanto seres contemporâneos ao MDF, na vida adulta já não compartilhavam da crença no trabalho e no progresso (pessoal, da família, do país) que havia marcado a vida dos seus pais e sido terreno fértil para ação militante de esquerda nos anos 1970. O solo no qual estes indivíduos cresceram e adentraram o mundo já foi também muito menos afeito às esperanças, até porque terrivelmente marcado pela violência (narrativas de vida de adolescentes e jovens destas regiões, hoje, necessariamente passam pela contabilidade de seus mortos) e pelo desemprego (que, como já foi bastante estudado, age como bloqueio relevante para a ação coletiva e popular nos marcos da política).

O MDF deu continuidade à sua atuação política e a seus contatos com as favelas da Zona Leste, mas a repetição da narrativa mobilizatória do movimento para os novos habitantes das periferias urbanas já não era mais inteligível. Até por isso, o movimento teve muita dificuldade para renovar seus quadros internos, e no início dos anos 2000 seus principais militantes ainda eram praticamente os mesmos que haviam iniciado as lutas na Vila Prudente, nos anos 1970. Além disso, outras organizações populares, religiosas e outros partidos políticos passaram a disputar um a um os votos e os consentimentos dos moradores das periferias - a sociedade civil ganhou, desde os anos 1990, uma dimensão concorrencial insuspeitada para os atores dos anos 1980. 
Mesmo que permaneça otimista, a contagem das organizações de base do MDF reduziu-se ao menos pela metade durante a década passada: no início dos anos 2000 o movimento passou a considerar que influía sobre cerca de 20 favelas da região, contra as 40 de quinze anos antes.

A virada do século trouxe a eleição de uma nova prefeitura do PT para a cidade de São Paulo, agora com Marta Suplicy. Doze anos depois da primeira experiência petista na prefeitura, as relações entre movimento, partido e Executivo municipal voltavam a ser baseadas no compartilhamento de um mesmo projeto político, mas já eram completamente distintas daquelas dos tempos de Erundina. Mais consolidados, institucionalizados e profissionalizados os canais de comunicação entre governos e sociedade civil, agora havia procedimentos previstos para as mediações entre o MDF e o Estado ${ }^{37}$, que ao fim de contas ficaram basicamente restritas a um tipo de mediação entre governo e setores favelados, na atuação do movimento em alguns programas de urbanização de favela.

Em 2001, por exemplo, a prefeitura municipal implementava um programa de canalização de córregos, e uma das obras se faria em São Mateus, passando pela favela Vergueirinho, há décadas vinculada ao MDF. A relevância técnica do programa era inquestionável, o risco e a precariedade em que viviam as 97 famílias faveladas alojadas sobre o córrego eram claros e justificavam sua remoção. Para viabilizar a desocupação destas famílias, a prefeitura petista acionou a rede de contatos populares do partido. Convocado para "ajudar" a prefeitura na remoção ${ }^{38}$ o MDF entrou em cena destacando uma das suas "lideranças de base" para a missão. Vizinha da área a ser

\footnotetext{
${ }^{37} \mathrm{O}$ que não significa que não haja espaços para as relações privadas entre esses atores, renovando as práticas tradicionais da relação entre sociedade e Estado no Brasil. Um estudo específico das relações entre os movimentos sociais e a gestão Marta Suplicy foi feito por Teixeira e Tatagiba (2005).

38 "Aí quando a Prefeitura foi lá a primeira vez, eu tava lá esperando a equipe da Prefeitura, para cadastrar as pessoas. Aí eu tinha que ir de porta em porta, chamando as pessoas, porque eu conhecia, né?” [Zefa].
} 
desocupada, Zefa conhecia suficientemente bem os moradores da favela Vergueirinho e desempenhou o papel fundamental, para a prefeitura, de intermediária entre a política pública e as famílias a serem remanejadas. Como me disse Zefa:

"Eu não dizia [para os moradores]: olha, eu vou cadastrar vocês, porque vocês vão sair daqui. Imagina! Não pode nem sonhar em falar isso! Até a prefeitura me falou assim: - olha, nós não vamos falar a verdade. Nós vamos [falar] assim: - nós vamos cadastrar vocês, vamos carimbar o barraco de vocês, pegar todos os dados da família, pegar a renda, porque nós estamos preocupados com essas famílias aqui, porque está vindo o rio aí, está vindo a estrada [a obra de canalização] e vai pegar quase que tudo aqui dessa favela. E vocês vão ficar [em situação ruim] ... a prefeitura não vai deixar prejudicar, vai ajudar vocês da melhor maneira possível. [...] Enquanto isso, vinham uns [funcionários da prefeitura] carimbando os barraquinhos e pegando os dados da família, renda e a quantidade de família. Foi uma coisa rápida da prefeitura." [Zefa]

O primeiro contato se fez assim, e deu certo; algum tempo depois, entretanto, foi preciso efetivamente "explicar" aos moradores que a saída deles dali era fato consumado. O movimento novamente ajudou: preparou uma reunião com as informações necessárias e suficientes para não gerar muita polêmica, 'tudo marcadinho no convite, pra não precisar explicar mais nada!'

Na reunião com os moradores, então:

"a prefeitura foi e falou tudo já concreto pra eles: - olha, vocês vão ganhar! Vocês vão sair daí, e vocês têm várias opções pra sair daí. Eram 97 famílias. Olha, vocês têm opções de ir pro Norte, quem quiser [voltar para a terra natal, no caso de migrantes]; outras vão para os apartamentos [em um conjunto habitacional em outra área], porque não tem 
apartamento pra todo mundo; [...] e outras vão ganhar uma verba de $R \$ 6.000$ a $R \$ 8.000$ pra comprar uma casinha na área municipal [em alguma outra favela, localizada em áreas de propriedade da prefeitura]." ${ }^{39}$ [Zefa]

A desocupação foi pacífica e ágil, sem nenhum conflito. O MDF trabalhou bem na missão de intermediação, foi elogiado pela prefeitura, e promoveu Zefa para a equipe de profissionais contratados pelo movimento. As políticas do PT funcionaram, as famílias foram removidas, e não foi preciso interromper as obras de canalização para limpar a área da favela. No debate corrente sobre políticas públicas e gestão urbana, este foi um caso exemplar de intervenção bem-sucedida.

\section{Entre o popular e a política: novas fronteiras}

Militantes do movimento me narraram diversas vezes o caso acima durante a pesquisa de campo, ressaltando a vantagem

110 relativa que ele demonstraria ainda existir no MDF, diante dos atores políticos tradicionais: o contato cotidiano com as favelas, a acessibilidade às "comunidades" cada vez mais fechadas, a concretude de sua nova forma de atuação. De tanto falarem neste caso, obrigaram-me a notar o que estava em jogo nele. De fato, a conformação recente da atuação do MDF revela toda uma nova trama de relações entre os setores populares e a política.

Como tantos outros atores sociais que emergiram nos anos 1980 e se inseriram na política nos 1990, o MDF de hoje não pode mais ser figurado como um sujeito que organiza as demandas e interesses sociais dos setores populares e as faz transitar ao espaço público. Nessa medida, o MDF não é mais especificamente um movimento social, mas aci-

\footnotetext{
${ }^{39}$ As duas primeiras opções eram, exatamente, as que a prefeitura municipal de São Paulo oferecia aos favelados durante os anos 1970, nas gestões Olavo Setúbal e Jânio Quadros, que tinham como premissa o desfavelamento. Foi justamente em reação a esta política que surgiu o MUF.
} 
ma de tudo um ator consolidado da esfera política, subalterno aos atores centrais de seu campo, como governos, partidos, financiadores de projetos etc.

$\mathrm{O}$ vetor da atuação política de atores como o MDF, em grande medida, se inverteu nas últimas décadas: eles deixaram de intermediar o acesso das demandas sociais populares ao mundo público e passaram majoritariamente a mediar o contrário, o acesso dos atores relevantes na esfera política aos setores populares (então vistos como público-alvo). Para um sistema político que se consolida, como o brasileiro, é preciso destacar que esta permanece sendo uma atuação relevante e positiva, por ao menos duas razões. Em primeiro lugar, porque a presença de atores como o MDF inseridos institucionalmente, ainda que de modo subalterno, é sinal da consolidação do sistema de participação social no Estado brasileiro, que efetivamente inseriu um conjunto extenso de organizações sociais na discussão pública ${ }^{40}$. Em segundo lugar, porque a existência deste conjunto de atores na esfera política permitiu, no período democrático, muito maior capilaridade social às políticas públicas, o que se comprova estatisticamente pela maior amplitude de acesso aos serviços sociais públicos nas periferias de São $\mathrm{Paulo}^{41}$. Escolas, creches, postos de saúde, centros de lazer, telefones públicos etc. são hoje muito mais presentes nos arredores das favelas assessoradas pelo MDF do que quando o movimento nasceu, o que representa também um incremento substancial no potencial de acesso a direitos sociais.

Entretanto, é justamente nesta inversão de sinal no vetor de atuação movimentista, e na lacuna que ela deixa na cena

\footnotetext{
${ }^{40}$ A comparação entre as transições democráticas na América Latina invariavelmente destaca a positividade do caso brasileiro, que efetivamente construiu inúmeros mecanismos formais e informais, ainda em desenvolvimento, de relações entre os setores sociais organizados e o Estado.

${ }^{41}$ Como demonstra a produção criteriosa do Centro de Estudos da Metrópole/Cebrap, compilada, por exemplo, em Marques e Torres (2005).
} 
pública, que aparece com maior nitidez a fronteira recente que se repõe entre os setores populares e a política. Não é difícil notar, ao fazer pesquisa nas favelas e periferias de São Paulo, que a presença pública de atores constituídos como o MDF, por mais positiva que seja, não consegue nem de longe traduzir a amplitude dos conflitos, demandas e anseios deste contingente de cidadãos em demanda política. O papel recente dos movimentos populares, de possibilitar a presença mais capilar dos atores políticos centrais entre os setores populares, não supre a necessidade contínua, e sempre renovada, de aparição pública e existência política dos novos habitantes da periferia urbana. Esta insuficiência é tão flagrante hoje, que em diferentes contextos de pesquisa nestes territórios não são os movimentos sociais, mas atores bem menos legítimos como o narcotráfico e as facções criminosas os que têm mediado a aparição das periferias no mundo público ${ }^{42}$.

Nesta nova figuração pública das camadas populares, sua 112 aparição legítima na esfera política é improvável, o que coloca em xeque o pressuposto que funda os regimes democráticos, qual seja, a garantia da pluralidade social representada legitimamente no mundo público. A conseqüência direta deste processo, recorrente em todo regime político não plural, é a reprodução da leitura dos não representados como "desviantes", seguida da disposição dos autoritarismos social e estatal para controlá-los. O bloqueio seletivo do acesso à legitimidade pública segue, portanto, sendo questão central da construção democrática até porque, nessa medida, continua a desenhar a face autoritária do sistema político brasileiro.

\section{Gabriel de Santis Feltran}

é doutorando em Ciências Sociais pela Unicamp

\footnotetext{
${ }^{42}$ Em Feltran (2006b) tento elaborar algumas das conseqüências deste fenômeno para pensar a política contemporânea. 


\section{Referências bibliográficas}

ANDRADE, C. M.; ROSSETTO, R. E BONDUKI, N. (orgs.). 1993. Arquitetura e habitação social em São Paulo: 1988-1992. São Paulo: EESC/USP.

AVRITZER, L.; NAVARRO, Z. (orgs.). 2003. A inovação democrática no Brasil. São Paulo: Cortez.

BAIERLE, S. G. 1992. Um novo princípio ético político: prática social e sujeito nos movimentos populares urbanos em Porto Alegre nos anos 80. Dissertação de mestrado, Campinas: IFCH-Unicamp.

BARCELLOS, C. 2004. Abusado: o dono do morro Dona Marta. $11^{\text {a }}$ ed. Rio de Janeiro: Record.

CARVALHO, M. do C. 1997. Eppur si muove... Os movimentos sociais e a construção da democracia no Brasil. Dissertação de mestrado, Campinas: IFCH-Unicamp. COSTA, S. 1997. "Contextos de construção do espaço público no Brasil”. Novos Estudos Cebrap, São Paulo, ${ }^{\circ} 47$.

DAGNINO, E. 1994a. "Os movimentos sociais e a emergência de uma nova noção de cidadania”. In: DAGNINO, E. (org.). Os anos 90: política e sociedade no Brasil. São Paulo: Brasiliense.

1994b. "On becoming a citizen: the story of D. Marlene". In: Benmayor, R; Skotnes, A. (orgs.). Intemational yearbook on oral history and life stories. Oxford: Oxford University Press.

2002. "Sociedade civil, espaços públicos e a construção demo-

crática no Brasil: limites e possibilidades”. In: DAGNINO, E. (org.). Sociedade civil e espaços públicos no Brasil. São Paulo: Paz e Terra.

; OLVERA, A.; PANFICHI, A. (orgs.). 2006. A disputa pela construção democrática na América Latina. São Paulo: Paz e Terra.

DOIMO, A. M. 1995. A vez e a voz do popular: movimentos sociais e participação política no Brasil pós-70. Rio de Janeiro: Relume Dumará/Anpocs.

EVERS, T. 1984. "Identidade: a face oculta dos movimentos sociais". Novos Estudos Cebrap, São Paulo, no 4, abril, pp. 11-23.

FELTRAN, G. de S. 2005. Desvelar a política na periferia: histórias de movimentos sociais em São Paulo. São Paulo: Humanitas/FAPESP.

2006a. "Deslocamentos: trajetórias individuais entre sociedade civil e Estado no Brasil”. In: DAGNINO, E.; OLVERA, A. \& PANFICHI, A. (orgs.). A disputa pela construção democrática na América Latina. São Paulo: Paz e Terra. . 2006b. "A fronteira do direito: violência e política na periferia de São Paulo". Artigo apresentado no $3^{\circ}$ Congresso Latino-Americano de Ciência Política: "Democracia e Desigualdades". Campinas: Unicamp. FERRÉZ. Capão pecado. 2005. Rio de Janeiro: Objetiva. 152p.

FRASER, N. 1995. "Rethinking public sphere - A contribution to the cri- 
tique of actually existing democracy". In: ROBBINS, B. (org.). The phantom public sphere. Minnesota: University of Minnesota Press.

GURZA LAVALLE, A.; HOUTZAGER, P.; CASTELLO, G. 2006. "Representação política e organizações civis: novas instâncias de mediação e os desafios da legitimidade”. Revista Brasileira de Ciências Sociais, vol. 21, n 60, pp. 43-66.

HABERMAS, J. 1992. "L'espace public 30 ans après". Quaderni, ${ }^{\circ}$ 18, automne, pp. 161-191. (Edição original em alemão: prefácio de Strukturwandel der Öffentlichkeit, 1990).

LINS, P. 1997. Cidade de Deus. São Paulo: Companhia das Letras.

MARQUES, E.; TORRES, H. (orgs.). 2005. São Paulo: segregação, pobreza urbana e desigualdade social. São Paulo: Senac.

OLIVEIRA, F. DE; PAOLI, M. C. (orgs.). 2000. Os sentidos da democracia. $2^{\text {a }}$ ed. Petrópolis: Vozes.

PAOLI, M. C. 1995. "Movimentos sociais no Brasil: em busca de um estatuto político". In: HELLMANN, M. (org.). Movimentos sociais e democracia no Brasil. São Paulo: Marco Zero/Ildesfes.

; TELLES, V. DA S. 2001. "Direitos sociais: conflitos e negociações no Brasil contemporâneo". In: ALVAREZ, S.; DAGNINO, E.; ESCOBAR, A. (orgs.). Cultura e politica nos movimentos sociais latino-americanos. Belo Horizonte: Editora UFMG.

114 RIBEIRO, A. C. T.; GRAZIA, G. de. 2003. Experiências de orçamento participativo no Brasil. São Paulo: Vozes.

SADER, E. 1988. Quando novos personagens entraram em cena: experiências, falas e lutas dos trabalhadores da Grande São Paulo, 1970-80. Rio de Janeiro: Paz e Terra. SANTOS, B. de S. 1994. Pela mão de Alice: o social e o político na pós-modernidade. $6^{\text {a }}$ ed. Porto: Afrontamento.

SOARES, L. E.; BILL, MV; ATHAYDE, C. 2005. Cabeça de porco. Rio de Janeiro: Objetiva.

TATAGIBA, L. 2003. Participação, cultura política e modelos de gestão: a democracia gerencial e suas ambivalências. Tese de doutorado, Campinas: IFCH-Unicamp. TEIXEIRA, A. C. C.; TATAGIBA, L. 2005. Movimentos sociais: o desafio da participação. São Paulo: Instituto Pólis/PUC-SP (Observatório dos Direitos do Cidadão: acompanhamento e análise das políticas públicas de São Paulo, n ${ }^{\circ}$ 25). TELLES, V. da S. 1994. "Sociedade civil e a construção de espaços públicos”. In: DAGNINO, E. (org.). Anos 90: política e sociedade no Brasil. São Paulo: Brasiliense.

; CABANES, R. (orgs.). 2006. Nas tramas da cidade: trajetórias urbanas e seus territórios. São Paulo: Humanitas.

ZALUAR, A. 2004. Integração perversa: pobreza e tráfico de drogas. $1^{\text {a }}$ ed. Rio de Janeiro: Editora FGV. 
Liberation Forces, until 1996, year of the first International Meeting for Humanity and Against Neoliberalism, organized in Mexican jungle, the Zapatista Army of National Liberation (ELZN) lived a slow and decisive transformation: from a classic guerrilla to a pacific movement which builds "one world that fits many worlds", through the invention of practices of participation and communication. This text analyses these new ways of doing politics that are being cultivated between the ELZN and what it calls "civil society", the countless groups connected to it through communication and solidarity ties.

Keywords: Zapatism; Civil society; Mexico.

\section{VINTE ANOS DEPOIS: A CONSTRUÇÃO DEMOCRÁTICA BRASILEIRA VISTA DA PERIFERIA DE SÃO PAULO}

\section{GABRIEL DE SANTIS FELTRAN}

Os movimentos sociais sempre buscaram estatuto político. Este artigo conta a história de um desses atores, o Movimento de Defesa do Favelado (MDF), que desde o final dos anos 1970 até os dias de hoje atua na periferia leste da cidade de São Paulo. Ao narrar essa história de trinta anos, vinte dos quais vividos sob a "nova democracia", o texto destaca as diferentes modalidades de relação entre os setores populares e a esfera política no Brasil contemporâneo. De um lado aparecem as tentativas de diluir a fronteira que bania, durante o regime autoritário, os segmentos populares da representatividade política; de outro lado, encontram-se novas fronteiras que, ainda que sob um regime pautado pela universalidade formal de direitos, se repõem hoje entre os setores populares e o mundo político.

Palavras-chave: Movimentos sociais; Periferia; São Paulo; Democracia; Representação. 


\section{TWENTY YEARS LATER: THE BRAZILIAN DEMOCRACY VIEWED FROM SÃO PAULO'S PERIPHERY}

Social movements always sought political status. This article tells the story of one of those actors, the Movement for the Defense of Favelados (MDF), which since the late 1970's operates in the eastern outskirts of the city of Sao Paulo. By telling this story of thirty years, twenty of which lived under the "new democracy", the text highlights the different forms of relationship between politics and popular sectors in the contemporary Brazil. On one side, there are some trends in direction of diluting the border that cut, during the authoritarian regime, the popular segments from the political representation. On the other side, there are new frontiers which even under a formal system based on the universality of rights, reappear today between the popular sectors and the political world.

Keywords: Social movements; Poverty; São Paulo; Democracy; Representation.

\section{MOVIMENTOS SOCIAIS COMO ACONTECIMENTOS: LINGUAGEM E ESPAÇO PÚBLICO}

\section{RICARDO FABRINO MENDONÇA}

De cunho conceitual, o presente artigo busca refletir sobre os processos de constituição e atuação de movimentos sociais com base na noção de acontecimento. A idéia é analisar a potência desestabilizadora que pode ser desencadeada por tais agências coletivas, que instauram práticas participativas fundamentais à democracia. Inicia-se essa discussão com uma sucinta apresentação do conceito de acontecimento, orientando-nos principalmente pelas idéias de Louis Quéré. Em seguida, busca-se estabelecer algumas relações entre tal conceito e os movimentos sociais, ressaltando a relevância das noções arendtianas de ação e refundação. Procura-se, então, evidenciar o caráter de acontecimento dos 